\title{
Cloud Computing Deployment Models: A Comparative Study
}

\author{
Prof. Hiral B. Patel ${ }^{1}$, Prof. Nirali Kansara ${ }^{2}$ \\ ${ }^{1}$ Assistant Professor, Achraya Motibhai Patel Institute of Computer Studies Ganpat University, Kherva India \\ ${ }^{2}$ Assistant Professor, JG College of Computer Applications, Gujarat University, India
}

Correspondence should be addressed to Hiral B. Patel; hiralben.patel@ganpatuniversity.ac.in

Copyright (C) 2021 Made Hiral B. Patel et al. This is an open access article distributed under the Creative Commons Attribution License, which permits unrestricted use, distribution, and reproduction in any medium, provided the original work is properly cite

\begin{abstract}
Cloud computing has become the embraced in the computer world. Cloud implementation is the process of creating a virtual computing environment. Deployment in the cloud provides organizations with flexible and scalable virtual computing resources. A cloud deployment model is the type of architecture in which a cloud system is deployed. These models differ in terms of administration, ownership, access control, and security protocols. This paper describes the different types of cloud computing service models and deployment models; it also gives us a comparative study of various clouds using many factors. The comparison is simply based on various factors such as reliability, cost, data control, workload, performance, and many other cloud parameters.
\end{abstract}

KEYWORDS-Deployment model, Service model, Public cloud, Private cloud, Hybrid cloud, Inter-Cloud, Federation cloud, Multi cloud.

\section{INTRODUCTION}

The demand for cloud computing has led to different types of cloud deployment models. Cloud computing is also known as the fifth utility (along with water, electricity, gas, and telephone) that is available based on user demand. Cloud computing is based on pay as per use of model. In this, a cloud computing model provides an on-demand online computing service as required by the user. [1] With all the new cloud options and the phrase "as a service" seemingly added to everything imaginable, it helps to take a step back and look at the differences between the main types of cloud deployment and the different types of services. cloud computing. Cloud deployment describes how a cloud platform is deployed, how it is hosted, and who has access to it. All cloud computing deployments operate on the same principle by virtualizing the computing power of servers into segmented, software-driven applications that provide compute and storage capabilities. [2] Like all clouds, they have different characteristics like storage capacities, billing systems, and different methods of providing the services of other clouds. The recent problem is that people do not know which cloud is suitable according to their requirements; they cannot choose the right cloud for their services among the different clouds managed by different cloud providers [3]. So, to facilitate these kinds of situations, this paper helps define the comparison of some of the most popular clouds, taking in mind. It's all the important aspects that can help a normal customer, business and academic organizations to choose the particular cloud from according to your needs. Briefly, this paper presents a comprehensive analysis of cloud computing, explaining its services and deployment models, identifying various features of interest, and comparing them with different deployment models.

\section{CLOUD COMPUTING SERVICES}

The cloud architecture can be divided into four layers based on their functioning which show in Fig.1.

\section{A.IaaS (Infrastructure as service) \\ B. PaaS (Platform as a Service) \\ C. FaaS (Function as a Service \\ D.SaaS (Software as a Service)}

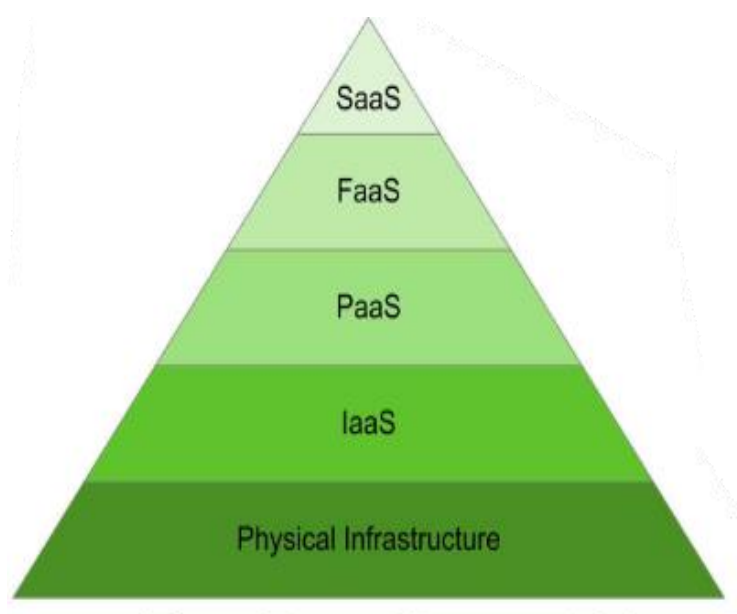

Fig 1: Classification of cloud services [4]

\section{A. Infrastructure as a Service (IaaS)}

IaaS is the most comprehensive and flexible type of cloud service. Essentially, it provides a fully virtualized computing infrastructure that is provisioned and managed over the Internet. An IaaS provider manages the physical edge of the infrastructure (servers, data storage space, etc.) in a data center, but allows customers to fully customize those virtualized resources to meet their specific needs. With IaaS, the customer can purchase, install, configure, and manage any software they need to use, including items such as operating systems, middleware, applications, business analytics, and development tools. IaaS eliminates the capital expense of building internal infrastructure. 
Examples of IaaS: Microsoft Azure, Amazon Web Services (AWS), Cisco Metacloud, Google Compute Engine (GCE). [2]

\section{B. Platform as a Service (PaaS)}

PaaS provides the framework you need to create, test, deploy, manage, and update software products. It uses the same basic infrastructure as IaaS, but also includes the operating systems, middleware, development tools, and database management systems necessary to create software applications. PaaS is extremely useful for any company that develops web-based software and applications. Many of the tools required to develop for multiple platforms (computers, mobile devices, browsers, etc.) can be quite expensive. Customers can access the development tools using PaaS cloud service.

Examples of PaaS: AWS Elastic Beanstalk, Apache Stratos, Google App Engine, Microsoft Azure. [2]

\section{Function-as-a-Service (FaaS)}

FaaS allows customers to react code reactively, without the need to allocate processing resources ahead of time. The cloud service provider handles the infrastructure, allowing the customer to focus strictly on the application of application codes. Functions are scaled automatically, making them excellent for adapting to dynamic workloads that vary in terms of resource consumption. Customers only pay for the resources they use, making FaaS the truest form of "pay-as-you-go" cloud computing. Most FaaS applications are quite simple and can be deployed very quickly. The cloud customer just needs to upload the complied function code and tell the platform how to provision resources when it executes.

Examples of FaaS: AWS Lambdas, Azure Functions. [2]

\section{Software as a Service (SaaS)}

SaaS is a fully developed software solution ready to buy and use over the Internet by subscription. The SaaS provider manages the infrastructure, operating systems, middleware, and data necessary to deliver the program, ensuring that the software is available when and where customers need it. Many SaaS applications run directly through web browsers, eliminating the need for downloads or installations.

SaaS applications allow businesses to get up and running quickly and scale operations quickly. You do not need to purchase or implement the hardware and software used to deliver your business services.

Examples of SaaS: Microsoft Office 365, Salesforce, Cisco WebEx, Google Apps. [2]

\section{CLOUD COMPUTING DEPLOYMENT MODELS}

There are six types of Deployment Models, from them five are main: Private Cloud, Public Cloud, Hybrid Cloud, Community Cloud, Virtual Private Cloud. Inter-Cloud is also a type of Deployment models and it has two types of clouds: Federated Clouds, Multi-clouds. In Fig. 2, it displays the uses of deployment models in Data center and its growth in present era and in future.

\section{A. Private Cloud}

The private cloud deployment model is also called as the internal or corporate model. A private cloud belongs to a specific organization. That organization controls the system and manages it centrally. While a third party (for example, a service provider) can host a private cloud server. Most companies choose to keep the hardware in their local data center. From there, an internal team can oversee and manage everything. [1]

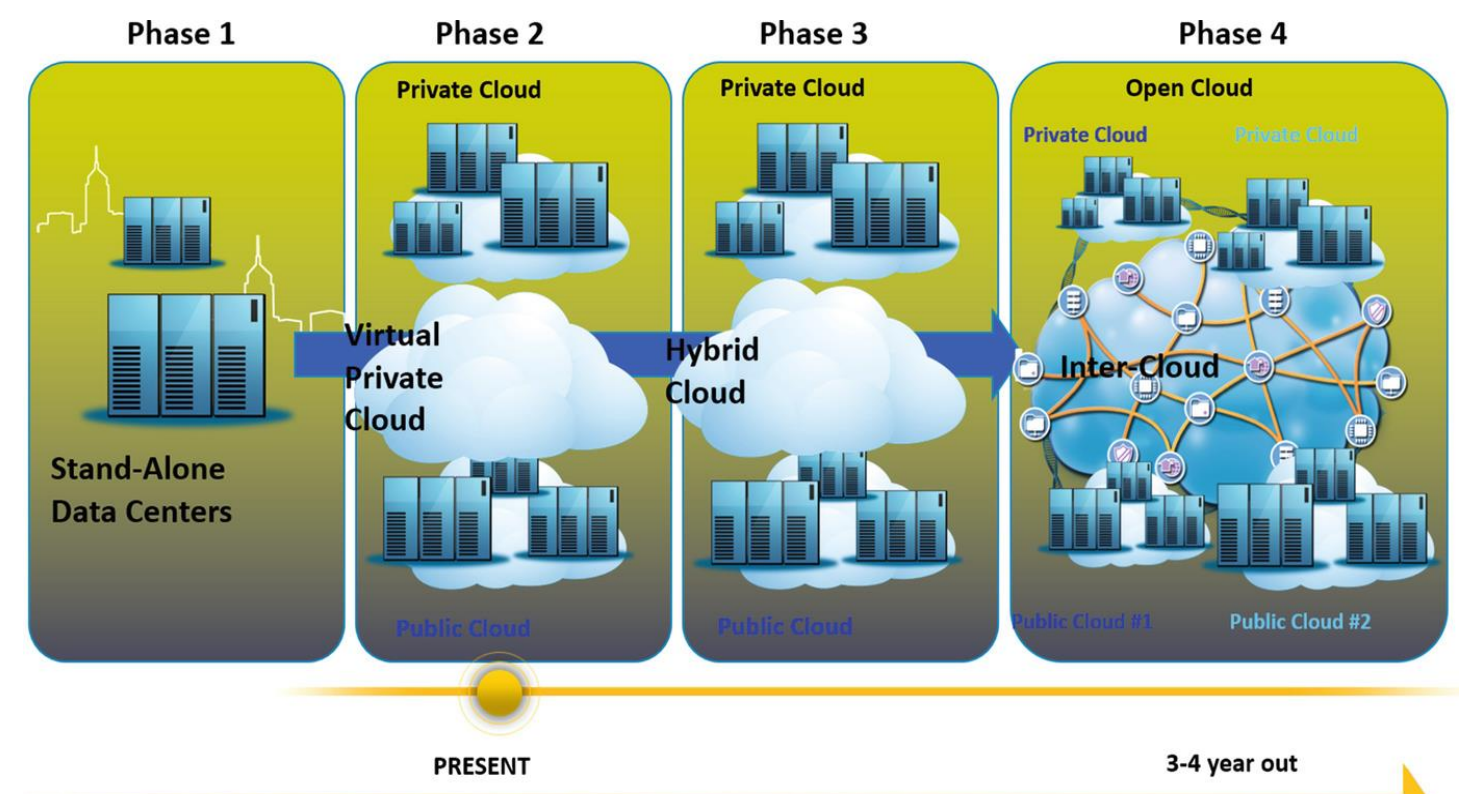

Federation / Workload Portability / Interoperability

Fig 2: Growth of Cloud models [14] 


\section{B. Public Cloud}

The public cloud model is well-known cloud service. This type of cloud is a popular choice for web applications, file sharing, and non-confidential data storage. Public clouds are recommended for software development and collaborative projects. The service provider owns and operates all the hardware necessary to run a public cloud. Vendors keep the devices in massive data centres. The public cloud delivery model plays an important role in development and testing. Developers frequently use public cloud infrastructure for development and testing purposes. Its virtual environment is inexpensive and can be easily configured and quickly deployed, making it perfect for test environments. [1]

\section{Hybrid Cloud}

Hybrid clouds combine public clouds with private clouds. They are designed so that data and applications move smoothly with each other and the two platforms interact smoothly. It is the perfect solution for a business or organization that needs a bit of both, which are generally industry and size dependent. [2] In essence, a hybrid cloud generally starts out as a private cloud which then extends the integration to use one or more public cloud services. This deployment model makes sense when companies have sensitive data that cannot be stored in the cloud or regulatory requirements that call for data protection, storage, and more. [6]

\section{Community cloud}

A cloud service that provides services to a community of users or organizations with shared interests or concerns. Organizations using this cloud service have shared missions, governance, security requirements, and policies. Cloud services can be hosted on the premises of the consumer organization, on the premises of the peer organization, at one provider, or a combination of these. This community cloud term is often used in marketing to explain the target consumers of the service, although the actual cloud could technically be a VPC, private or hybrid cloud model. [6]

\section{E. Virtual private cloud (VPC)}

A virtual private cloud (VPC) is a private cloud computing environment which is within a public cloud. Essentially, a VPC provisions logically isolated sections of a public cloud to provide a virtual private environment. Like all cloud environments, VPC resources are available on demand to scale as needed and are highly configurable. [8] This implementation is a compromise between a public and a private model in terms of price and features.

\section{F. Inter-Clouds}

Inter-cloud or "cloud of cloud" is a term that refers to a theoretical model for cloud computing services based on the idea of combining many different individual clouds into one seamless mass in terms of on-demand operations. Inter-cloud would simply ensure that a cloud could use resources beyond its reach, taking advantage of pre-existing contracts with other cloud providers. [9].
There are mainly two types of Inter-cloud:

- Multi Cloud

- Federated cloud (cloud federation)

\section{- Multi Cloud}

Multi-cloud is the use of two or more cloud computing services from several different cloud providers. A multi-cloud environment could be completely private, completely public, or a combination of both. Businesses use a multi-cloud environment to allocate computing resources and reduce the risk of downtime and data loss. They can also increase the computing power and storage available to businesses. Cloud innovations in recent years have led to a shift from single-user private clouds to multi-tenant public clouds and hybrid clouds. [10]

\section{- Federated cloud (cloud federation)}

A federated cloud is also called a cloud federation which is manage multiple internal and external cloud computing services for to meet business needs. A federation is the union of several smaller parties that perform a common action. [11] 


\section{COMPARISON OF CLOUD DEPLOYMENT MODELS}

Here is a comparative table that provides an overview of all six cloud deployment model based on many factors as listed below [1] [5][7] [12].

Table 1: Comparison Table among Six Types of Deployment Models.

\begin{tabular}{|c|c|c|c|c|c|c|}
\hline & Public & Private & VPC & Community & Hybrid & Inter \\
\hline Ease of Setup & $\begin{array}{l}\text { Very easy to } \\
\text { set up, the } \\
\text { provider does } \\
\text { most of the } \\
\text { work }\end{array}$ & $\begin{array}{l}\text { Very hard to } \\
\text { set up as your } \\
\text { team creates } \\
\text { the system }\end{array}$ & $\begin{array}{l}\text { Easy to set up, } \\
\text { the provider } \\
\text { does most of the } \\
\text { work (unless the } \\
\text { client asks } \\
\text { otherwise) }\end{array}$ & $\begin{array}{l}\text { Easy to set up } \\
\text { because of } \\
\text { community } \\
\text { practices }\end{array}$ & $\begin{array}{l}\text { Very hard to set } \\
\text { up due to } \\
\text { interconnected } \\
\text { systems }\end{array}$ & $\begin{array}{l}\text { Very easy to } \\
\text { set up, the } \\
\text { provider } \\
\text { does most of } \\
\text { the work }\end{array}$ \\
\hline Ease of use & $\begin{array}{l}\text { Very easy to } \\
\text { use }\end{array}$ & $\begin{array}{l}\text { Complex and } \\
\text { requires an } \\
\text { in-house team }\end{array}$ & Easy to use & $\begin{array}{l}\text { Relatively } \\
\text { easy to use as } \\
\text { members help } \\
\text { solve } \\
\text { problems and } \\
\text { establish } \\
\text { protocols }\end{array}$ & 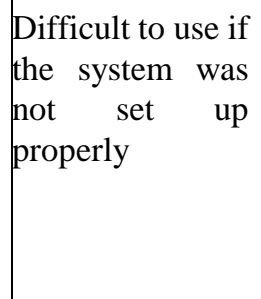 & Easy to use \\
\hline Data control & $\begin{array}{l}\text { Low, the } \\
\text { provider has } \\
\text { all control }\end{array}$ & $\begin{array}{l}\text { Very high as } \\
\text { yo-u own the } \\
\text { system }\end{array}$ & $\begin{array}{l}\text { Low, the } \\
\text { provider has all } \\
\text { control }\end{array}$ & $\begin{array}{l}\text { High (if } \\
\text { members } \\
\text { collaborate) }\end{array}$ & $\begin{array}{l}\text { Very high (with } \\
\text { the right setup) }\end{array}$ & $\begin{array}{l}\text { Very high } \\
\text { (with the } \\
\text { right setup) }\end{array}$ \\
\hline Reliability & $\begin{array}{l}\text { Prone } \quad \text { to } \\
\text { failures and } \\
\text { outages }\end{array}$ & $\begin{array}{l}\text { High (with the } \\
\text { right team) }\end{array}$ & $\begin{array}{lr}\text { Prone } & \text { to } \\
\text { failures } & \text { and } \\
\text { outages } & \end{array}$ & $\begin{array}{l}\text { Depends on } \\
\text { the } \\
\text { community }\end{array}$ & $\begin{array}{l}\text { High (with the } \\
\text { right setup) }\end{array}$ & $\begin{array}{l}\text { High(for } \\
\text { clients) }\end{array}$ \\
\hline Scalability & $\begin{array}{l}\text { Low, most } \\
\text { providers } \\
\text { offer limited } \\
\text { resources }\end{array}$ & $\begin{array}{l}\text { Very high as } \\
\text { there are no } \\
\text { other system } \\
\text { tenants }\end{array}$ & $\begin{array}{l}\text { Very high as } \\
\text { there are no } \\
\text { other tenants in } \\
\text { your segment of } \\
\text { the cloud }\end{array}$ & $\begin{array}{l}\text { Fixed } \\
\text { capacity } \\
\text { limits } \\
\text { scalability }\end{array}$ & $\begin{array}{l}\text { High (with the } \\
\text { right setup) }\end{array}$ & $\begin{array}{ll}\text { High } & \text { (with } \\
\text { the } & \text { right } \\
\text { setup) } & \end{array}$ \\
\hline $\begin{array}{l}\text { Security and } \\
\text { privacy }\end{array}$ & $\begin{array}{l}\text { Very low, not } \\
\text { a good fit for } \\
\text { sensitive data }\end{array}$ & $\begin{array}{l}\text { Very high, } \\
\text { ideal for } \\
\text { corporate data }\end{array}$ & $\begin{array}{l}\text { Very low, not a } \\
\text { good fit for } \\
\text { sensitive data }\end{array}$ & $\begin{array}{l}\text { High (if } \\
\text { members } \\
\text { collaborate } \\
\text { on security } \\
\text { policies) }\end{array}$ & $\begin{array}{l}\text { Very high as you } \\
\text { keep the data on } \\
\text { a private cloud }\end{array}$ & Very High \\
\hline $\begin{array}{l}\text { Setup } \\
\text { flexibility }\end{array}$ & $\begin{array}{l}\text { Little to no } \\
\text { flexibility, } \\
\text { service } \\
\text { providers } \\
\text { usually offer } \\
\text { only } \\
\text { predefined } \\
\text { setups }\end{array}$ & Very flexible & $\begin{array}{l}\text { Less than a } \\
\text { private cloud, } \\
\text { more than a } \\
\text { public one }\end{array}$ & $\begin{array}{l}\text { Little } \\
\text { flexibility, } \\
\text { setups are } \\
\text { usually } \\
\text { predefined to } \\
\text { an extent }\end{array}$ & Very flexible & Very flexible \\
\hline Cost & $\begin{array}{l}\text { Very } \\
\text { Inexpensive }\end{array}$ & $\begin{array}{l}\text { Very } \\
\text { expensive }\end{array}$ & Affordable & $\begin{array}{l}\text { Members } \\
\text { share the } \\
\text { costs }\end{array}$ & $\begin{array}{l}\text { Cheaper than a } \\
\text { private model, } \\
\text { pricier than a } \\
\text { public one }\end{array}$ & $\begin{array}{l}\text { Very } \\
\text { Inexpensive }\end{array}$ \\
\hline $\begin{array}{l}\text { Demand for } \\
\text { in-house } \\
\text { hardware }\end{array}$ & No & $\begin{array}{l}\text { In-house } \\
\text { hardware is } \\
\text { not a must but } \\
\text { is preferable }\end{array}$ & No & No & $\begin{array}{l}\text { In-house } \\
\text { hardware is not a } \\
\text { must but is } \\
\text { preferable }\end{array}$ & No \\
\hline
\end{tabular}




\begin{tabular}{|c|c|c|c|c|c|c|}
\hline Ownership & CSP & $\begin{array}{l}\text { Single } \\
\text { organization }\end{array}$ & CSP & $\begin{array}{l}\text { Several } \\
\text { organization }\end{array}$ & $\begin{array}{l}\text { Organization } \\
\text { and CSP }\end{array}$ & CSP \\
\hline Performance & $\begin{array}{l}\text { Low } \\
\text { medium }\end{array}$ & Excellent & Low & Very good & good & Excellent \\
\hline Location & Off premise & $\begin{array}{l}\text { Off or on } \\
\text { premise }\end{array}$ & On premise & $\begin{array}{l}\text { Off or on } \\
\text { premise }\end{array}$ & $\begin{array}{l}\text { Off or on } \\
\text { premise }\end{array}$ & On premise \\
\hline Managed by & CSP & $\begin{array}{l}\text { Single } \\
\text { organization }\end{array}$ & CSP & $\begin{array}{l}\text { Several } \\
\text { organization } \\
\text { or CSP }\end{array}$ & $\begin{array}{l}\text { Organization } \\
\text { and CSP }\end{array}$ & CSP \\
\hline $\begin{array}{l}\text { User's } \\
\text { control }\end{array}$ & $\begin{array}{l}\text { Limited } \\
\text { control }\end{array}$ & Full control & Full control & $\begin{array}{l}\text { High control } \\
\text { but limited by } \\
\text { community } \\
\text { policies }\end{array}$ & $\begin{array}{l}\text { Full control over } \\
\text { private part and } \\
\text { limited at public } \\
\text { part }\end{array}$ & Full control \\
\hline Workload & $\begin{array}{l}\text { Normal } \\
\text { workload with } \\
\text { short-spikes } \\
\text { in demand }\end{array}$ & $\begin{array}{l}\text { Not } \quad \text { suitable } \\
\text { for } \quad \text { handling } \\
\text { large } \\
\text { workload }\end{array}$ & $\begin{array}{lr}\text { Suitable } & \text { for } \\
\text { handling } & \text { high } \\
\text { workload } & \end{array}$ & $\begin{array}{l}\text { Suitable for } \\
\text { handling } \\
\text { large } \\
\text { workload }\end{array}$ & $\begin{array}{l}\text { Highly dynamic } \\
\text { or changeable }\end{array}$ & $\begin{array}{l}\text { Highly } \\
\text { dynamic or } \\
\text { changeable }\end{array}$ \\
\hline $\begin{array}{l}\text { Size of Data } \\
\text { Center }\end{array}$ & $\begin{array}{l}\text { Around } \\
50,000 \mathrm{~s}\end{array}$ & $\begin{array}{l}\text { Around } \\
50,000 \mathrm{~s}\end{array}$ & $\begin{array}{l}50000>\mathrm{TO} \\
<80000\end{array}$ & $\begin{array}{l}\text { Public cloud } \\
>\quad 15000> \\
\text { Private cloud }\end{array}$ & $\begin{array}{l}\text { Less than private } \\
\text { cloud }\end{array}$ & $\begin{array}{l}\text { More than } \\
\text { hybrid cloud }\end{array}$ \\
\hline Used By & $\begin{array}{l}\text { Anyone can } \\
\text { access }\end{array}$ & $\begin{array}{l}\text { Limited } \\
\text { people can } \\
\text { access }\end{array}$ & $\begin{array}{l}\text { Depend on } \\
\text { Authorization } \\
\text { of the user }\end{array}$ & $\begin{array}{l}\text { Depend upon } \\
\text { number of } \\
\text { cooperatives }\end{array}$ & $\begin{array}{l}\text { Medium } \\
\text { accessibility }\end{array}$ & Any client \\
\hline
\end{tabular}

\section{CONCLUSION}

Cloud computing has transformed the way businesses around the world do business in a way that many people are unaware of. Understanding the difference among various types of cloud computing and identifying which one is best suited for a growing business is tremendously important. This paper provides the knowledge of the introduction to cloud computing, its concepts, models and services. The paper also discusses the comparison of all cloud computing deployment models in table form. These clouds are compared against supported platforms, supported languages, storage capacity, services, and products. Fig. 3 shows Public cloud is the most popular general deployment option, with a usage share of over $61 \%$. Traditional on-premises deployment, with just under half (49\%) of shared use, ranks second. Hybrid cloud, which combines public cloud services with on-premises private cloud infrastructure, ranks third, with approximately $39 \%$ usage. The study encouraged respondents to choose from several of the five cloud deployment options. It shows a tenth (9\%) selected all five, and almost a fifth (19\%) selected four out of five. Among them two-thirds $(64 \%)$ selected at least two cloud deployment options. The upshot is that while the public cloud is by far the most popular choice, most of the organizations surveyed employ a mix of cloud types. Interestingly, multi-cloud or the use of multiple cloud computing and storage services in a single homogeneous network architecture had the fewest users (24\% of respondents).

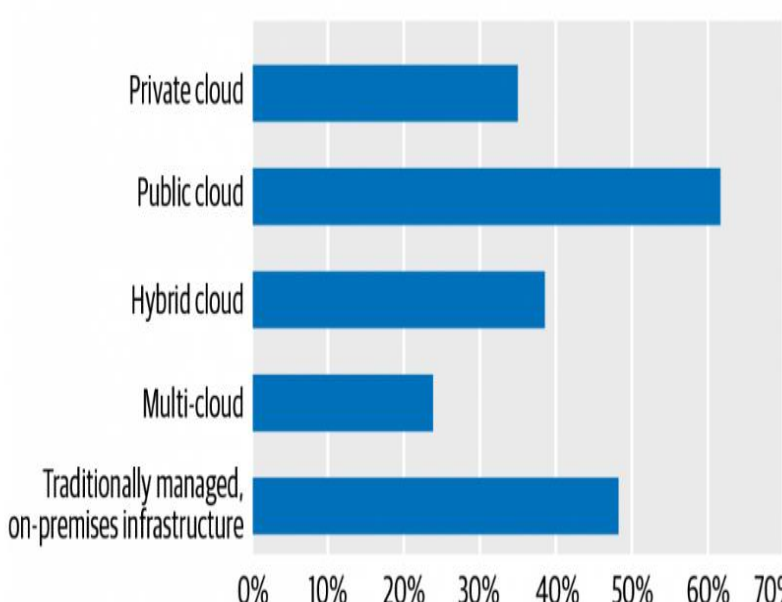

Fig 3: Cloud Computing Technology Market Analysis by Type [13]

\section{CONFLICTS OF INTEREST}

The authors declare that they have no conflicts of interest.

\section{REFERENCES}

[1] https://phoenixnap.com/blog/cloud-deployment-models 
[2] https://www.vxchnge.com/blog/different-types-of-cloud-co mputing

[3] http://jungleg.com/2011/04/15/rackspace-cloud-vs-amazon-c loud-which-is-the-winner/

[4] https://www.infoq.com/presentations/aaas-iaas-paas-serverle ss

[5] S. Saranya, Dr R Manicka Chezian - Cloud Computing: Deployment model, Service model, Data base and Computing system, International Journal of Innovations \& Advancement in Computer Science-Volume 5, Issue-9, Sep-2016

[6] https://crmtrilogix.com/Cloud-Blog/Cloud-Models/Cloud-D eployment-Models-and-Hybrid-Cloud-Computing/132

[7] Ahmed E. Youssef-Exploring Cloud Computing Services and Applications, Journal of Emerging Trends in Computing and Information Sciences, VOL. 3, NO. 6, July 2012

[8] https://www.checkpoint.com/cyber-hub/cloud-security/whatis-vpc-virtual-private-cloud

[9] https://www.bbvaopenmind.com/en/technology/digital-worl d/cloud-clouds-intercloud https://avinetworks.com/glossary/multi-cloud

[10] https://whatis.techtarget.com/definition/federated-cloud-clou d-federation

[11] Mohammad Haris, Rafiqul Zaman Khan-A Systematic Review on Cloud Computing, International Journal of Computer Sciences and Engineering Volume 6, Issue-11, Nov-2018

[12] https://www.oreilly.com/radar/cloud-adoption-in-2020/

[13] Naresh Kumar Sehgal,Pramod Chandra P. Bhatt,John M. Ac ken-Features of Private and Public Cloud, Cloud Computing with Security. Springer, 05 September 2019

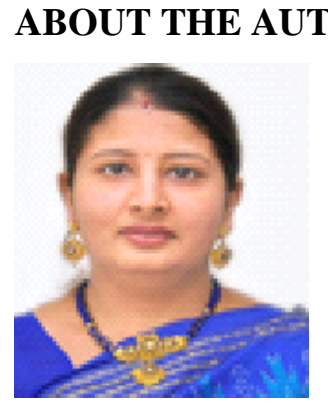

Prof. Hiral B. Patel received her B.Sc. and M.Sc. (Computer Application \& Information Technology) from Hemchandracharya North Gujarat University (HNGU), Patan, Gujarat, India. She Published many Research Paper in National Journal. She Published a Book regarding Question Bank of Computer Networking. She is an Assistant Professor at Achraya Motibhai Patel Institute of Computer Studies, Ganpat University, Gujarat, India. She has Teaching experience of 13 years in BCA. Her area of interest includes Cloud computing, Computer Network, Wireless Networking, Web Development Technology.

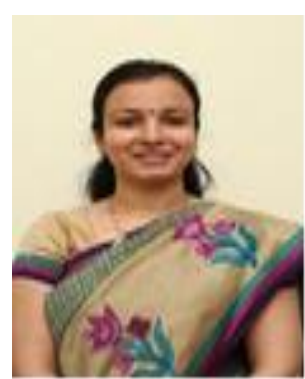

Prof. Nirali Kansara received her BCA and MCA from NSVKMS MCA College, Visnagar, Gujarat, India. She is an Assistant Professor at JG College of Computer Applications, Gujarat University, Gujarat, India. She has Teaching experience of 14 years in BCA. Her area of interest includes Cloud computing, Cyber Security, IOT. 